\title{
Study on the Development of Rural E-Commerce against the Backdrop of Rural Revitalization
}

\author{
Qingxiang Wang \\ Sichuan University of Arts and Science, Dazhou, China \\ Email: 1062148831@qq.com
}

How to cite this paper: Wang, Q.X. (2018) Study on the Development of Rural E-Commerce against the Backdrop of Rural Revitalization. Open Journal of Social Sciences, 6, 1-7.

https://doi.org/10.4236/jss.2018.67001

Received: September 10, 2017

Accepted: July 10, 2018

Published: July 13, 2018

Copyright $\odot 2018$ by author and Scientific Research Publishing Inc. This work is licensed under the Creative Commons Attribution International License (CC BY 4.0).

http://creativecommons.org/licenses/by/4.0/

\section{(c) (i) Open Access}

\begin{abstract}
Under the trend of "Internet+", the analysis of the development of rural e-commerce will reveal some of its deficiencies such as a single booster, the lack of standards of the products, the difficulties of building the local logistics system, as well as the lack of effective distribution stations. The paper will discuss the current development situation of rural e-commerce, especially the bottlenecks in the development process, and will propose a "Four-Step" strategy to break the deadlock from the perspective of rural revitalization. Those steps are as follows: firstly, improve the traceability system of product quality to boost consumer confidence; secondly, give play to comparative advantages and create regional agricultural brands with distinguishing features; thirdly, take the big data center of rural e-commerce as the fulcrum to lever the inventory of agricultural products; lastly, bring about the innovation and upgrading of related industries as well as industrial transformation and reconstruction to further promote the revitalization of rural areas.
\end{abstract}

\section{Keywords}

Rural Area, E-Commerce, Logistics, Rural Revitalization

\section{Introduction}

In recent years, the per capita disposable income and actual consumption expenditure of rural residents in China have been growing at a higher rate than that of urban residents, which manifests that the upgrading of rural consumption has been gradually accelerating. At the same time, the number of netizens in rural areas has been increasing year by year, with the proportion of the total number of netizens in China increasing from $26.5 \%$ in 2011 to $28.4 \%$ in 2015, 
which opens up more room for the growth of rural online shopping market. In a word, rural e-commerce, which is stepping into the fast track of higher quality development, plays an increasingly prominent role in optimizing rural industrial structure and boosting structural reforms in the agricultural supply side, adding new momentum to rural revitalization [1].

\section{The Current Situation of Rural E-Commerce in China}

\section{1) The capacity of rural online shopping market has been amplified}

In 2017, the retail revenue of rural physical products nationwide totaled 78.66 billion yuan, a year-on-year increase of $35.1 \%$, accounting for $14.28 \%$ of the country's total.

Relevant experts predicted that the compound growth rate of the number of rural e-commerce parcels will reach $46 \%$ in 2018-2020. Rural e-commerce will become a vital engine for the development of regional economies in many areas. Related data shows that in 2015, the total volume of China's rural e-commerce market reached 353 billion yuan, with a year-on-year increase of $94.3 \%$, accounting for $9.3 \%$ of the whole online shopping market; in 2016, it reached 660.8 billion yuan. It is estimated that by the end of 2018 China's rural e-commerce market will reach 1261.6 billion yuan, a year-on-year increase of $36 \%$, accounting for $19.4 \%$ of the online shopping market. By the end of 2020, China's rural e-commerce market will reach 1.6919 billion yuan.

\section{2) Intensified market competition of rural e-commerce industry}

With the escalation of price competition in the domestic market, overseas purchases have come to market in succession. This year, under the pressure of a sharp drop in investment returns, a reduction in demographic dividends, rising costs in labor force and a rigid rise of costs in aging and environmental pollution, the potential growth rate of China's economy has been decreasing. On the contrary, there has been a gradually accelerated growth in the rural market, which is sprayed with strangling warfare among e-commerce giants. Therefore, rural e-commerce has been developing by leaps and bounds, which is playing an important role in leading domestic consumption demand of rural areas, reshaping the industrial structure, as well as promoting coordinated development of urban and rural areas. An increasing number of people of insight have gradually recognized the opportunities for the prospect of rural e-commerce. Many major e-commerce companies have deployed their strategies in rural areas one after another, such as Alibaba, JD, and Suning, which all regard rural areas as one of their targeted market. For example, Alibaba projected the "Thousand Counties and Ten Thousand Villages" plan, which means that investing 10 billion yuan to establish 2000 county-level operation centers and 200,000 village-level small service stations. Based on its original distribution station, JD also invested 5 billion RMB in 2200 districts and counties across the country to establish its own warehouse and logistics system, and launch county-level service centers and "JD Gang" service stations. By the end of 2017, it has realized the nationwide cover- 
age of logistics network in all administrative villages. In 2015, China Post established 110,000 rural offline outlets, 275 operating centers and 100 warehouse and distribution centers. Suning Commerce group co., LTD. has built 10,000 service stations covering 14 percent of the country's townships.

\section{3) A beneficial political environment for rural e-commerce}

The CPC Party and Chinese government have been paying highly attention to the "Blue Ocean" market (potential market). The government has played a role in two aspects to promote the development of rural e-commerce. Firstly, strengthen the infrastructure construction. On the one hand, in the process of promoting the "Broadband China" project, it is necessary to realize full coverage of broadband in administrative villages while promoting the speed of the Internet and reducing fees. On the other hand, it proposed to build and improve a cross-regional cold chain logistics system for agricultural products and implement the "Express Delivery to the Countryside" project. Besides, the government also implemented policies of encouraging and supporting the development of small and micro enterprises, which can enjoy relevant preferential policies in accordance with their own conditions and needs.

The government has changed the idea of rural e-commerce work, and lays more emphasis on rural e-commerce to improve the "soft power" of the rural economy. In 2014, the Central Document No. 1 proposed "Strengthening the construction of e-commerce platform for agricultural products" with more emphasis on the hardware construction of rural e-commerce. The Central Document No. 1 issued in 2015 proposed to "support e-commerce, logistics, trading, finance, and other enterprises to participate in the construction of e-commerce platform for agriculture to set an integral model of promoting e-commerce in rural areas" again. The central document issued in 2016 emphasized that reducing the logistics costs of agricultural products was the focus of the central government's work. It proposed to accelerate the formation of a two-way logistics network in rural area, which is "a two-way distribution pattern of online and offline integration, agricultural products entering the city, means of agricultural production and consumer goods transferred to the countryside". The Central Document No. 1 of 2018 proposed that "Strive to build a comprehensive infrastructure to promote the development of rural e-commerce; encourage and support various market players to innovate and develop a new type of agricultural industry based on the Internet; speed up the implementation of e-commerce and intensify the comprehensive demonstration of rural e-commerce to accelerate the modernization of rural circulation", which has further specified the direction for the development of rural e-commerce in China.

\section{The Bottlenecks during the Development of Rural E-Commerce}

Currently, rural e-commerce not only plays a leading role in "transporting industrial products to the countryside", to enrich farmers' consumption options, 
but also helps "upstream agricultural products" to open up new paths for farmers to achieve prosperity.

\section{1) A single booster to the development of rural e-commerce}

The vision of developing rural e-commerce is to take root in rural areas, serve farmers, and benefit farmers at the largest extent. In fact, there are new requests for rural e-commerce emerging from actual operation when rural areas expect to diversify their products and promote them to the national market. The rural e-commerce platform is required to integrate relevant resources in the supply chain to provide managing support and payment methods for the operators of producing, marketing and providing service on the network. During specific operation, those companies need not only the support of governments, enterprises, retailers, and urban consumers, but also the participation of logistics service providers, certification centers, financial institutions, regulatory agencies, and other related organizations. In the development of rural e-commerce, interest coordination and benefit distribution will become the key issues in the supply chain management and control for there are many participants.

\section{2) The lack of standards of rural e-commerce products}

The quality standards for the products sold on network platforms are not unified. At present, many e-commerce platforms of agricultural products are facing a difficulty that they have not reached a break even. This phenomenon is closely related to relatively low overall quality of agricultural products and not unified quality standards of products on those platforms. The cyclical characteristics plus diversified types without unified standards of agricultural products made it difficult to categorize green agricultural products, organic agricultural products, pollution-free agricultural products, and China's geographical indication products ("three kinds of products and one indication product"). Therefore, the products sold on those platforms cannot satisfy consumer, who pursue high-quality and healthy agricultural products [2].

\section{3) It is difficult to build a logistics system within the same city}

China has a vast territory with relatively scattered rural residents, who have low commercial awareness. Besides, poor basic infrastructures, decentralized competition-free advantages, long production cycles of agriculture-related products, long chains, and asymmetric information made it is difficult to control the supply chain of agricultural products. Some companies try to integrate the business flow, persuade the distributors to put the product online, and then centralize the distribution according to the online orders, so that dealers focus on sales, e-commerce operators handle logistics, thereby reducing transportation costs and improving distribution efficiency. However, most dealers, who have independent warehouses and distribution systems, are unwilling to invest in cost and energy, which makes it difficult to build a local logistics system [3].

4) The lack of effective "distribution stations" in the rural logistics system

On the one hand, the overall distribution area is very broad. In order to achieve full coverage of rural outlets, some enterprises have established service 
stations in several hundred administrative villages, but there are fewer freight vehicles that provide long-term delivery services, some companies even have only 3 vehicles. After receiving an online order, the company determines the delivery route based on the distance of the location and the quantity, which greatly limits the distribution efficiency and has caused dissatisfaction among service station workers. On the other hand, despite ignoring low efficiency of centralized distribution, some companies have long been in a state of deficit due to problems such as too long a one-way transportation route. Among the service stations established within the county, the farthest one needs to detour about 100 kilometers to reach, such a long distance makes the distribution cost really high. We can learn from this phenomenon that the "last mile" of logistics system in rural areas is still a difficulty. The way to solve this problem may not be to set up service stations in each village, but to establish truly effective cargo distribution points.

\section{The Countermeasures to Break the Dilemma}

As China's economy enters the stage of new normal, rural area is in urgent need of solving the problem of selling agricultural products with high speed, freshness, and quality guaranteed. At present, the "structure adjustment and capacity reduction" advocated in the supply-side structural reform, provides a new direction and path for solving the current dilemma of rural e-commerce and promoting the development of e-commerce platform [4].

1) Improve the traceability system of product quality to boost consumer confidence

The traceability system of agricultural products, which is not only the source of products, but also ensures the product quality to build consumers' confidence, is an important form of guarantee for providing consumers with high-quality, healthy and nutritious agricultural products. Therefore, new-type of agricultural management entities such as family farms, specialized households, farmers' cooperatives, and industrialized leading agricultural enterprises should all together play a pivotal role in jointly building a source tracing system for rural agricultural products, by relying on the network trading platform of rural e-commerce and complying with the trend of development, to improve the quality of agricultural products and increase consumers' confidence towards agricultural products.

2) Give full play to the comparative advantages and create regional agricultural brands with distinctive features

Firstly, priority should be given to developing e-commerce of agricultural products with comparative advantages or regional characteristics to comprehensively standardize the whole process from packaging, signage, and transportation to storage to increase the added value of agricultural products. At the same time, the strategy of brand promotion should be implemented to form a hierarchical, gradient development model of rural e-commerce, which can promote the de- 
velopment of general products with characteristics. As a result, these measures will enhance consumers' trust in the quality of agricultural products and the recognition of agricultural products' brands as well as further standardize the online market of agricultural products.

3) Take the big data center of rural e-commerce as the entry point to achieve the supply-side reform goal of agricultural products destocking and structural adjustment

Being in digital era is a new way of living based on information technology in modern society. In such a digital environment, people's ways of production, thinking, and behaving all present a new look.

The establishment of big data center of rural e-commerce transaction requires the leading of government or third-party agencies, based on the rural e-commerce network trading platform by the means of modern cloud technology. Both government and third-party entities should focus on the data analysis functions to provide information of agricultural products on the demand of different consumers of various regions and types for agricultural products, which will guide farmers to combine their own advantages, adjust the structure and scale of agricultural production, and etc. to match market demand and optimize supply structure. In addition, information sharing and feedback functions should be highlighted, which means that we should develop an open, transparent, interactive and shared information feedback module of the resources of agricultural products on the data analysis platform, through which, information symmetry between farmers and consumers was achieved. On the one hand, peasant households can share their problems or good solutions in production, circulation, sales, and etc. to get help through open-source discussions. On the other hand, consumers can give the information about personalized demand and timely evaluate the quality of purchased agricultural products, the service attitude of farmers, and the response time of logistics, and then put forward opinions and suggestions [5].

4) Bring about the innovation and upgrading of related industries and industrial restructuring

E-commerce should not only conduct online trading activities, but also deal with offline production, which is a two-pronged approach. In other words, the development of e-commerce will drive the development of supporting industries such as producing, processing, storage, logistics and e-commerce services. Those industries can replace some outdated enterprises that have to be eliminated, helping traditional enterprises to advance with the times; achieve transformation, creating new types of industries that meet the principles of comprehensive development, like logistics. Besides, they can inject new economic vitality into the development of townships, directly provide more employment opportunities for the farmers as well, which will finally promote the transformation and reconstruction of the entire county, and promote the development and revitalization of rural areas. 


\section{Founding}

Project of Sichuan Research Center of Electronic Commerce and Modern Logistics Opened in 2018 (DSWL18-14).

\section{References}

[1] Tao, H. (2015) The Development of Rural E-Commerce for Agricultural Products in China. Xin Nong Ye, No. 22, 20-24.

[2] Zhang, J.L. and Yin, Q. (2015) Developing Rural E-Commerce to Promote Agricultural Products into the City. China Business, No. 4, 75-76.

[3] Wang, Q.X. (2017) Analysis on the B2C Model of Logistics Distribution of Agricultural Products Based on the E-Commerce Model. Journal of Commercial Economics, No. 14, 92-94.

[4] Zhao, J.T. (2014) Analysis of the Application of E-Commerce of Characteristic Agricultural Products in Lin'an City. Master's Thesis, Zhejiang A \& F University, Hangzhou.

[5] Chen, J.H. and Ye, C. (2015) Analysis of Rural E-Commerce and Its Distinctive Development Process. Logistics Engineering and Management, No. 10, 95-96. 